\title{
STRATEGI PENGELOLAAN SANGGAR GONG SITIMANG DALAM MELESTARIKAN MUSIK TRADISIONAL MELAYU JAMBI
}

\author{
Arnia Hartipa Iskandar \\ Program Studi Magister Tata Kelola Seni, Program Pascasarjana \\ Institut Seni Indonesia Yogyakarta \\ Jl. Suryodiningratan No. 8, Suryodiningratan, Kec. Mantrijeron, Kota Yogyakarta, Kode Pos 55143 \\ Daerah Istimewa Yogyakarta. Indonesia \\ Email: arniahartipa1996@gmail.com
}

\begin{abstract}
Abstrak
Sanggar Gong Sitimang merupakan sanggar musik bernuansa melayu Jambi yang didirikan oleh seniman Jambi bernama Zulkarnain pada tahun 2000, sanggar ini didirikan sebagai wadah bagi pecinta seni musik untuk mengembangkan skill dan kreativitas dalam kesenian tradisional. Tujuan penelitian ini adalah untuk menganalisis dan mengkaji tentang pengelolaan sanggar seni musik tradisional gong sitimang yang masih eksis dan bertahan di zaman modernitas. Tulisan ini merupakan deskritif kualitatif dengan menggunakan alat pengumpulan data berupa observasi dan wawancara. Analisis data dilakukan dengan metode SWOT untuk mengkaji permasalahan baik dari faktor internal dan eksternal. Sumber data penelitian ini adalah Pendiri Sanggar, Pengelola Sanggar, dan Key Person. Hasil penelitian pengelolaan Sanggar Gong Sitimang dari hasil analisa matrik IE posisi Sanggar Gong Sitimang ini beerada di posisi IV, dimana sanggar gong sitimang menunjukkan Growth and Build yang artinya tumbuh dan bina. untuk variasi strategi yang cocok pada sanggar gong sitimang ini adalah Intensif atau Integrasi. Sedangkan menurut hasil kuadran SWOT posisi sanggar gong sitimang berada pada kuadran I yaitu Strategi generik Ekspansion. Jadi variasi strategi yang digunakan adalah ofensif (variasi strategi kuadran SWOT), Intensif \& Integrasi (variasi strategi dari matrik IE).
\end{abstract}

Kata Kunci: strategi pengelolaan, gong sitimang.

\begin{abstract}
Sanggar Gong Sitimang is a Jambi Malay music studio founded by a Jambi artist named Zulkarnain in 2000, this studio was founded as a forum for music lovers to develop skills and creativity in traditional arts. The purpose of this research is to analyze and study the management of the traditional music art studio Gong Sitimang which still exists and survives in modernity. This paper is descriptive qualitative using data collection tools in the form of observation and interviews. Data analysis was performed using the SWOT method to assess problems from both internal and external factors. The data sources of this research are the studio founders, studio managers, and key persons. The results of the research on the management of Sanggar Gong Sitimang from the results of the IE matrix analysis, the position of the Gong Sitimang Studio was in position IV, where the Gong Sitimang studio showed Growth and Build which means growth and development, a variety of strategies that are suitable in this Gong Sitimang studio is Intensive or Integration. Meanwhile, according to the results of the SWOT quadrant the position of the Gong Sitimang studio is in quadrant I, namely the generic expansion strategy. The variations of the strategies used are offensive (variations of the SWOT quadrant strategy), Intensive \& Integration (variations of strategies from the IE matrix).
\end{abstract}

Keywords: management strategy, gong sitimang.

\section{PENDAHULUAN}

Sanggar seni di Provinsi Jambi sangat berperan penting dalam melestarikan kebudayaan dan kesenian tradisional. Dampak dari fenomena ini membuat perkembangan sanggar seni di Jambi cukup pesat. Melihat perkembangan sanggar seni yang cukup pesat, membuat sanggar-sanggar yang ada di Jambi berlomba-lomba menjadi yang terbaik supaya dapat menarik perhatian masyarakat luas, baik dari segi pengelolaan dan pemasarannya. Sekian banyak jumlah Sanggar di Jambi, salah satu Sanggar seni menurut peneliti yang aktif dalam seni pertunjukan yaitu Sanggar Gong Sitimang. Sanggar ini cukup sering tampil dan berpatisipasi dalam setiap acara dan kegiatan seni yang diselenggarakan di Jambi.

Sanggar Gong Sitimang merupakan satu-satunya sanggar bernuansa music melayu Jambi yang didirikan 
oleh seniman Jambi bernama Zulkarnain pada tahun 2000. Tujuan Sanggar Gong Sitimang didirikan sebagai wadah bagi generasi muda untuk berkreativitas dan mengembangkan bakat/skill dalam kesenian tradisional, serta tempat bermain bagi anak anak muda untuk melakukan hal yang bermafaat. Selain itu Sanggar ini telah menghasilkan regenerasi yang menjadi asset sebagai pelestari kesenian tradisional Jambi.

Potensi Sanggar Gong Sitimang di era modernitas ini cukup besar diantara sanggar-sanggar lain di Kota Jambi. Hal ini dapat dilihat dari pengalaman pertunjukan musik tradisional yang pernah diikuti di Jambi maupun luar Jambi. Salah satu event yang pernah diikuti adalah Festival Karawitan Indonesia, yang diselenggarakan oleh Disparbud pada tahun 2012, di festival ini Sanggar Gong Sitimang menjadi perwakilan dari Provinsi Jambi untuk berpatisipasi dalam festival tersebut. Tentunya pengalaman mengikuti festival ini menjadi pengalaman yang momental bagi Sanggar Gong Sitimang, karena Sanggar Gong Sitimang terpilih oleh Dinas Pariwisata Jambi dan di saat pertunjukan sanggar ini masuk lima besar terbaik di Indonesia. Maka dari itu dengan adanya pengalaman pertunjukan inilah Sanggar Gong Sitimang membangun relasi dan mitra kerjanya. Selain itu, untuk karya musik dari Sanggar Gong Sitimang sudah cukup banyak mengaransemen lagu daerah Jambi dan menciptakan karya musik tradisional melayu Jambi.

Pengelolaan Sanggar Gong Sitimang di bentuk pada tahun 2000 dibawah kepengurusan Zulkarnain dan anak-anaknya, tentunya sanggar ini bersifat kekeluargaan. Selain dari pengelolaan struktur organisasi yang melibatkan keluarga, sanggar ini sangat konsisten dalam melestarikan kesenian tradisional, meskipun banyak sanggar-sanggar baru yang bermunculan dengan konsep modern tidak mempengaruhi kekonsitennan Sanggar ini. Tetapi yang uniknya walaupun sanggar ini adalah sanggar music tradisional, sanggar Gong Sitimang masih tetap eksis dikalangan masyarakat dan generasi muda.

Perkembangan Sanggar Gong Sitimang dari pertama didirikan hingga sekarang, tentunya pernah mengalami pasang surut dalam berkarya dan pertunjukan. Berbagai zaman sudah dilalui dalam berkesenian baik perubahan generasi pemusik yang silih berganti dalam sanggar ini. hal ini tentunya memerlukan pengelolaan yang baik dan handal. Sehingga Sanggar Gong Sitimang tetap eksis dikalangan masyarakat. Maka dari itu perlulah peneliti mengetahui bagaimana bentuk pengelolaan Sanggar Gong Sitimang yang masih bertahan melestarikan music tradisional melayu Jambi hingga saat ini yang dilihat dari faktor internal dan eksternalnya.

\section{KAJIAN TEORI}

\section{Analisis $S W O T$}

Menurut Rangkuti (2016:10) Analisis SWOT adalah metode perencanaan strategis yang digunakan untuk mengevaluasi kekuatan (strengths), kelemahan (weaknesses), peluang (opportunities), dan ancaman (threats) dalam suatu proyek atau suatu spekulasi bisnis. Keempat faktor itulah yang membentuk akronim SWOT (strengths, weaknesses, opportunities, dan threats).

Menurut Erwin (2016:130) dalam Skripsi yang berjudul Analisis SWOT dalam Penentuan Strategi Pemasaran untuk Peningkatan Penjualan Mesin Diesel: Studi pada Toko Sinar Teknik Kutuarjo oleh Albertus (2020) mengatakan bahwa "Analisis SWOT adalah metode perencanaan strategis yang digunakan untuk mengevaluasi kekuatan atau Strengths, kelemahan atau Weaknesses, peluang atau Opportunities, dan ancaman atau Threats dalam suatu proyek atau spekulasi bisnis. Dan dapat diterapkan dengan cara menganalisis dan memilah berbagai hal yang mempengaruhi keempat faktornya" Jadi Analisis SWOT merupakan sebuah cara atau metode perencanaan strategis yang digunakan untuk mengevaluasi kekuatan, kelemahan, peluang, dan ancaman dalam suatu organisasi untuk spekulasi bisnis. Proses ini melibatkan dan mengidentifikasi faktor internal dan eksternal yang dapat mendukung organisasi dalam mencapai tujuan tersebut.

\section{Faktor-Faktor Analisis SWOT}

Didalam analisis SWOT terdapat faktor-faktor yang menjadi indikator dalam melakukan analisis yaitu terdiri dari empat faktor sebagai berikut: Menurut Sondang (2000:173) ada pembagian faktor-faktor strategis dalam analisis SWOT yaitu:

\section{1). Faktor Kekuatan (Streghts)}

Maksud dari faktor-faktor kekuatan yang dimiliki oleh suatu perusahaan termasuk satuan-satuan bisnis didalamnya. Seperti sumber keterampilan, produk andalan kualitas layanan. Faktor kekuatan ini membuat suatu organisai lebih kuat dari pada pesaing dalam memuaskan kebutuhan pasar yang sudah dan direncanakan.

\section{2). Faktor Kelemahan (Weaknesses)}

Maksud dari kelemahan ialah keterbatasan atau kekurangan dalam hal sumber, keterampilan, dan 


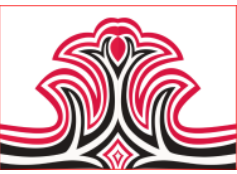

kemampuan yang menjadi penghalang serius bagi penampilan kinerja organisasi yang memuaskan.

\section{3). Faktor Peluang (Opportunities)}

Definisi peluang secara sederhana peluang ialah berbagai situasi lingkuangan yang menguntungkan bagi suatu satuan bisnis.

\section{4). Faktor Ancaman (Threats)}

Pengertian ancaman merupakan kebalikan pengertian peluang yaitu faktor-faktor lingkungan yang tidak menguntungkan suatu satuan bisnis jika jika tidak diatasi ancaman akan menjadi bahaya bagi satuan bisnis yang bersangkutan baik unutk masa sekarang maupun dimasa depan.

\section{Analisis Matriks $I E$}

Analisis Matriks IE (Internal-Eksternal) merupakan bagian tahap pencocokkan dengan memasukkan hasil pembobotan matriks Evaluation Factor Ekesternal (EFE) dan Internal Factor Evaluation (IFE) kedalam matrik IE. Matriks IE mempunyai Sembilan sel strategi yang dapat dikelompokkan menjadi tiga sel strategi utama, yaitu pada Tabel 1 (David, 2016):

Tabel 1. Bentuk Matriks $I E$

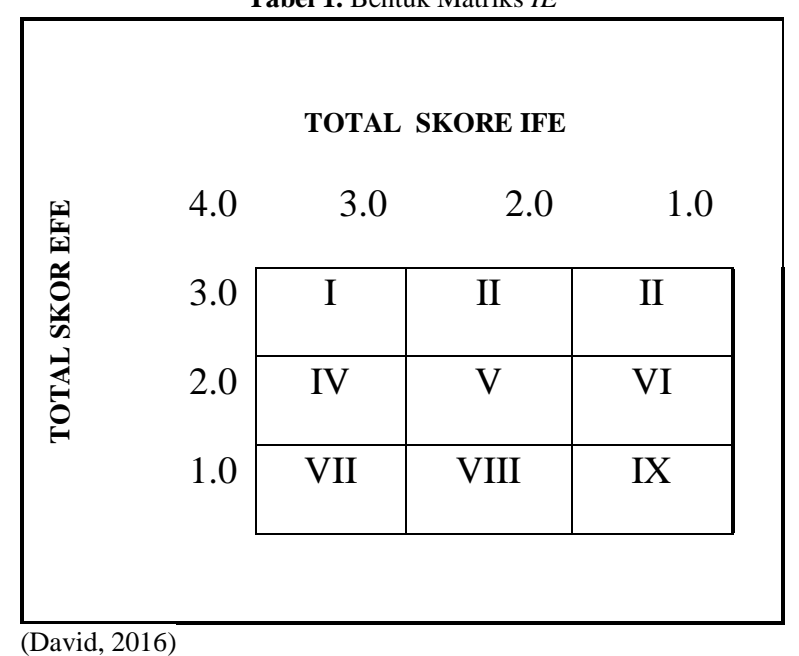

a). Growth and Build berada dalam sel I, II, dan IV. Strategi yang tepat yaitu intensif, yaitu penetrasi pasar, pengembangan pasar, dan pengembangan produk, atau integrasi yaitu integrasi ke belakang, integrasi ke depan dan integrasi horizontal, b). Hold and Maintain dilakukan untuk sel III, V, dan VII. Strategi umum yang cocok adalah penetrasi pasar dan pengembangan produk, dan c). Harvest or Divest dipakai untuk sel VI, VIII, dan IX. Strategi umum yang digunakan yaitu strategi divestasi, strategi diversifikasi konglomerat, dan strategi likuidasi.
Gorga : Jurnal Seni Rupa

Volume 10 Nomor 02 Juli-Desember 2021 p-ISSN: 2301-5942 | e-ISSN: 2580-2380

\section{METODE PENELITIAN}

Metode penelitian yang digunakan dalam penelitian ini adalah deskriptif kualitatif. Menurut Sugiyono (2011:21) menyatakan bahwa Metode deskriptif adalah metode yang digunakan untuk menggambarkan atau menganalisis suatu hasil penelitian tetapi tidak digunakan untuk membuat kesimpulan yang lebih luas. Jadi jenis penelitian ini adalah penelitian secara deskriptif supaya memperoleh penulisan yang jelas dan menggambarkan keadaan sebenarnya bagaimana proses pengelolaan yang saat ini sedang dilakukan oleh Sanggar Gong Sitimang.

\section{Tempat dan Waktu Penelitian}

Penelitian ini dilakukan di wilayah Kota Jambi, Jl. H. M. Yusuf Singedijane Purnawira Rt. 22 No. 22 Kelurahan Sungai Putri, Kecamatan Danau, Jambi. Waktu penelitian dilakukan pada tanggal 03 Maret 2021.

\section{Teknik Pengumpulan Data}

Teknik pengumpulan data yang digunakan adalah observasi dan wawancara yang dilakukan di Sanggar Gong Sitimang.

\section{1). Observasi}

Observasi dilakukan pada tanggal 04 maret 2021. Observasi ini juga menggunakan alat pengumpulan data seadanya berupa buku catatan kecil lapangan dan ingatan peneliti. Observasi ini dilakukan di lokasi Sanggar Gong Sitimang. Adapun yang peneliti lakukan saat proses observasi dilakukan, yaitu melihat kegiatan, aktivitas, proses latihan dan pementasan pertunjukan yang dilakukan oleh pengelola dan pemusik di Sanggar Gong Sitimang.

\section{2). Wawancara}

Wawancara pada penelitian ini dilakukan dengan cara mendapatkan data dari narasumber/informa Sanggar Gong Sitimang pada subjek yang telah ditentukan, yaitu Pendiri Sanggar, Key Person dan Pengelola Sanggar. Didalam wawancara ini peneliti menggunakan alat bantu berupa media rekam, handphone dan buku catatan kecil.

\section{HASIL DAN PEMBAHASAN}

\section{Hasil}

\section{1). Analisis $S W O T$}

Analisis SWOT adalah merupakan salah satu metode perencanaan strategis yang digunakan untuk mengevaluasi kekuatan (strengths), kelemahan (weaknesses), peluang (opportunities), dan ancaman (threats) dalam suatu proyek atau organisasi (Kartika, 2017). Dari hasil perkumpulan data yang diperoleh 


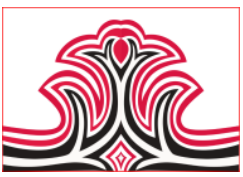

peneliti dalam menganalisis faktor internal dan eksternal (EFE dan IFE) Sanggar Gong Sitimang, peneliti menemukan hal-hal penting yang terkait dengan pengelolaan sanggar sebagai berikut:

Tabel 2. Kekuatan (Strengths)

\begin{tabular}{|c|c|}
\hline No & Kekuatan \\
\hline 1 & $\begin{array}{l}\text { Sudah berdiri sejak tabun } 1990 \\
\text { (Berpengalaman) }\end{array}$ \\
\hline 2 & $\begin{array}{l}\text { Mempunvai Karakter Tersendiri dalam } \\
\text { Karva musik tradisional melaus iambi } \\
\text { yang mengikuti perkembangan zaman }\end{array}$ \\
\hline 3 & Seni yang memprioritas generasi muda \\
\hline 4 & $\begin{array}{l}\text { Memiliki tenaga pengajar blusan sekolab } \\
\text { seni musik dan sudah berpengalaman } \\
\text { dibidangnya. }\end{array}$ \\
\hline 5 & $\begin{array}{l}\text { Pengemasan kpnsep latihan yang menarik } \\
\text { dan lreatif }\end{array}$ \\
\hline 6 & $\begin{array}{l}\text { Memiliki bubungan baik dengan para } \\
\text { konsumen }\end{array}$ \\
\hline 7 & $\begin{array}{l}\text { Dinercavai oleh pemecintah, Masxarakat } \\
\text { dan Media (telexigi dan radio) untuk } \\
\text { meneigi acara kegenian di Jambi }\end{array}$ \\
\hline 8 & Memiliki fajilitas yang lengkan \\
\hline
\end{tabular}

Tabel 3. Kelemahan (Weaknesses)

\begin{tabular}{|c|c|}
\hline No & Kelemaban \\
\hline 1 & $\begin{array}{l}\text { Pengelolaan manaiemen sanggar seni yang } \\
\text { belum maksimal }\end{array}$ \\
\hline 2 & $\begin{array}{l}\text { Belum mampu melakukan pemetasan } \\
\text { sendiri untuk tinglat nasional }\end{array}$ \\
\hline 3 & Kuranewra Promosi di Media Sosial \\
\hline 4 & $\begin{array}{l}\text { Belum jelasuya patoksa barga ketika di } \\
\text { tawari pentas }\end{array}$ \\
\hline
\end{tabular}

Tabel 4. Peluang (Opportunities)

\begin{tabular}{|c|c|}
\hline No & Peluang \\
\hline 1. & Belum banyak Sanggar Seni yang sejenis. \\
\hline 2. & $\begin{array}{l}\text { Antusjasme anak-anak dalam mengikuti } \\
\text { kegiatan geni gangat tinggi }\end{array}$ \\
\hline 3. & $\begin{array}{l}\text { Relestanian nilai Budaya Iradisional } \\
\text { Melayu Jambi }\end{array}$ \\
\hline 4. & $\begin{array}{l}\text { Membuka lapangan kerja untuk para } \\
\text { seniman Jambi }\end{array}$ \\
\hline 5. & $\begin{array}{l}\text { Renyewaan fasilitas yang dimiliki sanggar. } \\
\text { untuk masyarakat sekitar }\end{array}$ \\
\hline 6. & Renyelenggaraan kegiatan lomba seni \\
\hline
\end{tabular}

Tabel 5. Ancaman (Threats)

\begin{tabular}{|c|c|}
\hline No & Ancaman \\
\hline 1. & $\begin{array}{l}\text { Rerubahan sosial budaya, linghangan } \\
\text { demografi dan elonomi }\end{array}$ \\
\hline 2. & $\begin{array}{l}\text { Kemungkinan besar akan muncul pesaing } \\
\text { baru ganggar geni musik yang geienis. }\end{array}$ \\
\hline 3. & $\begin{array}{l}\text { Prochlu pengganti beroma biburan yang } \\
\text { bukan seni Tradisional }\end{array}$ \\
\hline 4. & $\begin{array}{l}\text { Renenus generasi muda semakin malu } \\
\text { untuk berkegenian }\end{array}$ \\
\hline 5. & Sumbar dava yane mulai berknrane \\
\hline
\end{tabular}

\section{(1). Tahap Pemasukan}

Dalam tahap pemasukan, peneliti menggunakan alat bantu kuesioner kepada masing-masing informa yaitu Zulkarnain (pendiri), Syafwan (key person) dan
Gorga : Jurnal Seni Rupa

Volume 10 Nomor 02 Juli-Desember 2021 p-ISSN: 2301-5942 | e-ISSN: 2580-2380

Zamzami Akbar (Pengelola), data yang disajikan melalui beberapa tabel sebagai berikut:

\section{a. Pemberian Bobot}

Pemberian bobot merupakan tingkat kepentingan suatu faktor terhadap keberhasilan organisasi dalam suatu kinerjanya. Pada pemberian/penentuan bobot penelitian ini diperoleh dari data internal dan eksternal yang dianalisis peneliti dengan mengajukan penyebaran kuisioner kepada informa yaitu Zulkarnain (pendiri), Syafwan (key person) dan Zamzami Akbar (Pengelola), Berikut ini rangkuman pemberian bobot dalam Sanggar Gong Sitimang:

Tabel 6. Pemberian Bobot Faktor Internal (Kekuatan \& Kelemahan) Sanggar Gong Sitimang

\begin{tabular}{|c|c|c|c|c|}
\hline $\begin{array}{c}\text { Factor } \\
\text { Internal }\end{array}$ & $\begin{array}{c}\text { Bapak } \\
\text { Zul }\end{array}$ & Syafuan & $\begin{array}{c}\text { Zama } \\
\text { Zami } \\
\text { Akbar }\end{array}$ & $\begin{array}{c}\text { Rata- } \\
\text { Rata }\end{array}$ \\
\hline A & 0.095 & 0.091 & 0.121 & 0.102 \\
\hline B & 0.087 & 0.077 & 0.098 & 0.087 \\
\hline C & 0.087 & 0.093 & 0.083 & 0.088 \\
\hline D & 0.102 & 0.073 & 0.102 & 0.092 \\
\hline E & 0.095 & 0.069 & 0.083 & 0.082 \\
\hline F & 0.079 & 0.096 & 0.08 & 0.085 \\
\hline G & 0.076 & 0.096 & 0.072 & 0.081 \\
\hline H & 0.102 & 0.05 & 0.091 & 0.081 \\
\hline I & 0.072 & 0.077 & 0.061 & 0.070 \\
\hline J & 0.057 & 0.123 & 0.072 & 0.084 \\
\hline K & 0.076 & 0.066 & 0.068 & 0.070 \\
\hline L & 0.072 & 0.089 & 0.068 & 0.076 \\
\hline \multicolumn{5}{|c|}{ Total Rata-Rata } \\
\hline
\end{tabular}

Keterangan:

A = Sudah berdiri sejak tahum 1990 (Berpengalaman)

B = Mempunyai Karakter Tersendiri dalam Karya musik tradisional melayu jambi yang mengikuti perkembangan zaman

$\mathrm{C}=$ Sanggar seni yang memprioritas generasi muda

D = Memiliki tenaga pengajar lulusan sekolah seni musik dan sudah berpengalaman dibidangnya

$\mathrm{E}=$ Pengemasan konsep latihan yang menarik dan kreatif

$\mathrm{F}=$ Memiliki hubungan baik dengan para konsumen

$G$ = Dipercayai oleh pemerintah, Masyarakat dan Media (televisi dan radio) untuk mengisi acara kesenian di Jambi

$\mathrm{H}=$ Memiliki fasilitas yang lengkap

I = Pengelolaanimanajemen sanggar seni yang belum maksimal

$\mathrm{J}$ = Belum mampu melakukan pemetasan sendiri untuk tingkat nasional

$\mathrm{K}=\mathrm{Kurangnya}$ Promosi di Media Sosial

$\mathrm{L}$ = Belum jelasnya patokan harga ketika di tawari pentas

Pada Tabel 6 di atas menunjukkan bahwa faktor internal Sanggar Gong Sitimang (dilihat dari rata-rata) yang memiliki bobot tertinggi adalah "A = Sudah berdiri sejak tahun 1990 (Berpengalaman)" dan bobot yang terendah adalah "I = Pengelolaan/manajemen sanggar seni yang belum maksimal" dan " $\mathrm{K}=$ Kurangnya Promosi di Media Sosial". 
Tabel 7. Pemberian Bobot Faktor Eksternal (Peluang \& Ancaman) Sanggar Gong Sitimang

\begin{tabular}{|c|c|c|c|c|}
\hline $\begin{array}{l}\text { Falatox } \\
\text { Internal }\end{array}$ & $\begin{array}{c}\text { Bapak } \\
\text { Zul }\end{array}$ & Syafixan & $\begin{array}{c}\text { Zama } \\
\text { Zami } \\
\text { Akbar } \\
\end{array}$ & $\begin{array}{l}\text { Rata- } \\
\text { Rata }\end{array}$ \\
\hline A & 0.112 & 0.086 & 0.123 & 0.107 \\
\hline $\mathrm{B}$ & 0.091 & 0.064 & 0.077 & 0.077 \\
\hline $\mathrm{C}$ & 0.073 & 0.059 & 0.068 & 0.067 \\
\hline $\mathrm{D}$ & 0.103 & 0.064 & 0.086 & 0.084 \\
\hline $\mathrm{E}$ & 0.151 & 0.091 & 0.109 & 0.117 \\
\hline $\mathrm{F}$ & 0.073 & 0.064 & 0.059 & 0.065 \\
\hline $\mathrm{G}$ & 0.091 & 0.104 & 0.082 & 0.092 \\
\hline $\mathrm{H}$ & 0.073 & 0.109 & 0.086 & 0.089 \\
\hline I & 0.082 & 0.118 & 0.100 & 0.100 \\
\hline $\mathrm{J}$ & 0.082 & 0.123 & 0.095 & 0.100 \\
\hline $\mathrm{K}$ & 0.069 & 0.118 & 0.114 & 0.100 \\
\hline \multicolumn{4}{|c|}{ Total Rata-Rata } & 1.000 \\
\hline
\end{tabular}

Keterangan:

A = Belum banyak Sanggar Seni yang sejenis

B = Antusiasme anak-anak dalam mengikuti kegiatan sen sangat tinggi

C = Pelestarian nilai Budaya Tradisional Melayu Jambi

D = Membuka lapangan kerja untuk para seniman Jambi

$\mathrm{E}=$ Penyewaan fasilitas yang dimiliki sanggar untuk masyarakat sekitar

F = Penyelenggaraan kegiatan lomba seni musik Tradisional Melayu Jambi yang diikuti oleh masyarakat Jambi

$\mathrm{G}=$ Perubahan sosial budaya, lingkungan demografi dan ekonomi

$\mathrm{H}=$ Kemungkinan besar akan muncul pesaing baru sanggar seni musik yang sejenis

I = Produk pengganti berupa hiburan yang bukan sen Tradisional

$\mathrm{J}=$ Penerus generasi muda semakin malu untuk berkesenian

$\mathrm{K}$ = Sumber daya yang mulai berkurang

Pada tabel 7 menunjukkan bahwa faktor eksternal Sanggar Gong Sitimang (dilihat dari rata-rata) yang memiliki bobot tertinggi adalah " $\mathrm{E}=$ Penyewaan fasilitas yang dimiliki sanggar untuk masyarakat sekitar" dan bobot yang terendah adalah " $\mathrm{F}=$ Penyelenggaraan kegiatan lomba seni musik Tradisional Melayu Jambi yang diikuti oleh masyarakat Jambi”.

\section{b. Pemberian Peringkat}

Peringkat menggambarkan seberapa efektif strategi organisasi atau perusahaan saat ini dalam merespon faktor strategis yang ada. Penilaian peringkat untuk lingkungan diberikan dalam skala dengan pembagian sebagai berikut:

\section{a). Lingkungan Eksternal}

Aspek Peluang;
rating 4 = respon sangat
superior,
rating 3 = respon di atas
rata-rata,
rating 2 = respon rata-
rata, dan
rating 1 = respon di
bawah rata- rata

Aspek Ancaman:

rating 4 = respon di

bawah rata-rata.

rating 3 = respon rata-

rata,

rating 2 = respop di atas

rata-rata, dan

rating 1 = respon sangat

superior

\section{b). Lingkungan Internal}

$\begin{array}{ll}\text { Aspek Kekuatan: } & \text { Aspek Kelemaban: } \\ \text { rating } 4 \text { = sangat buat, } & \text { rating } 4=\text { sangat lemah, } \\ \text { rating } 3=\text { kuat, } & \text { rating } 3=\text { lemah, } \\ \text { rating } 2=\text { lemah dan } & \text { rating } 2=\text { kuat, dan } \\ \text { rating } 1=\text { sangat lemah } & \text { rating } 1=\text { sangat buat }\end{array}$

Berikut ini pemberian peringkat dalam Sanggar Gong Sitimang. Dalam usaha ini key person ada 3 orang yaitu Bapak Zulkarnain, Syafwan, dan Zam Zami Akbar.

\section{(a). Kekuatan}

Tabel 8. Pemberian Peringkat Faktor Kekuatan Sanggar Gong Sitimang

\begin{tabular}{|c|c|c|c|c|c|}
\hline No & Kekuatan & Zul & SW & Zami & $\begin{array}{l}\text { Rata- } \\
\text { Rata }\end{array}$ \\
\hline 1. & $\begin{array}{l}\text { Sudah berdiri sejak } \\
\text { tahun } 1990 \\
\text { (Berpengalaman) }\end{array}$ & 4 & 3 & 4 & 3.667 \\
\hline 2. & $\begin{array}{l}\text { Mempunyai } \\
\text { Karakter Tersendiri } \\
\text { dalam Karya musik } \\
\text { melayu jambi yang } \\
\text { mengikuti } \\
\text { perkembangan } \\
\text { zaman }\end{array}$ & 4 & 4 & 4 & 4.000 \\
\hline 3. & $\begin{array}{l}\text { Seni yang } \\
\text { memprioritas } \\
\text { generasi muda }\end{array}$ & 4 & 4 & 4 & 4.000 \\
\hline 4. & $\begin{array}{l}\text { Memiliki tenaga } \\
\text { pengajar lulusan } \\
\text { sekolah seni musik } \\
\text { dan sudah } \\
\text { berpengalaman } \\
\text { dibidangnya }\end{array}$ & 4 & 3 & 3 & 3.333 \\
\hline 5. & $\begin{array}{l}\text { Pengemasan konsep } \\
\text { latihan yang } \\
\text { menarik dan kreatif }\end{array}$ & 4 & 3 & 4 & 3.667 \\
\hline 6. & $\begin{array}{l}\text { Memiliki hubungan } \\
\text { baik dengan para } \\
\text { konsumen }\end{array}$ & 3 & 3 & 3 & 3.000 \\
\hline 7. & $\begin{array}{l}\text { Dipercayai oleh } \\
\text { pemerintah, } \\
\text { Masyarakat dan } \\
\text { Media (televisi dan } \\
\text { radio) }\end{array}$ & 4 & 4 & 4 & 4.000 \\
\hline 8. & $\begin{array}{l}\text { Memiliki fasilitas } \\
\text { yang lengkap }\end{array}$ & 3 & 4 & 3 & 3.333 \\
\hline
\end{tabular}

Berdasarkan Tabel 8, peringkat terhadap kekuatan Sanggar Gong Sitimang yang terendah adalah "Memiliki hubungan baik dengan para konsumen". Sedangkan peringkat yang tertinggi ada 3 yang mempunyai nilai yang sama yaitu "Mempunyai Karakter Tersendiri dalam Karya musik tradisional melayu jambi yang mengikuti perkembangan zaman, Seni yang memprioritas generasi muda, dan Dipercayai oleh pemerintah, Masyarakat dan Media (televisi dan radio) untuk mengisi acara kesenian di Jambi”. 
(b). Kelemahan

Tabel 9. Pemberian peringkat Faktor Kelemahan Sanggar Gong Sitimang

\begin{tabular}{|c|l|c|c|c|c|}
\hline No & \multicolumn{1}{|c|}{ Kelemahan } & Zul & SW & Zami & $\begin{array}{c}\text { Rata- } \\
\text { Rata }\end{array}$ \\
\hline 1. & $\begin{array}{l}\text { Pengelolaan/mana } \\
\text { jemen sanggar } \\
\text { seni yang belum } \\
\text { maksimal }\end{array}$ & 1 & 3 & 2 & 2.000 \\
\hline 2. & $\begin{array}{l}\text { Belum mampu } \\
\text { melakukan } \\
\text { pemetasan sendiri } \\
\text { untuk tingkat } \\
\text { nasional }\end{array}$ & 2 & 3 & 2 & 2.333 \\
\hline 3. & $\begin{array}{l}\text { Kurangnya } \\
\text { Promosi di Media } \\
\text { Sosial }\end{array}$ & 2 & 3 & 2 & 2.333 \\
\hline 4. & $\begin{array}{l}\text { Belum jelasnya } \\
\text { patokan harga } \\
\text { ketika di tawari } \\
\text { pentas }\end{array}$ & 2 & 4 & 2 & 2.667 \\
\hline
\end{tabular}

Berdasarkan tabel 9, peringkat terhadap kelamahan Sanggar Gong Sitimang yang terendah adalah "Pengelolaan/manajemen sanggar seni yang belum maksimal”. Sedangkan peringkat yang tertinggi adalah "Belum jelasnya patokan harga ketika di tawari pentas".

\section{(c). Peluang}

Tabel 10. Pemberian Peringkat Faktor Peluang Sanggar Gong

\begin{tabular}{|c|c|c|c|c|c|}
\hline \multicolumn{6}{|c|}{ Sitimang } \\
\hline No. & Peluang & Zul & Sw & Zam & $\begin{array}{l}\text { Rata- } \\
\text { Rata }\end{array}$ \\
\hline 1. & $\begin{array}{l}\text { Belum banyak } \\
\text { Sanggar Seni } \\
\text { yang sejenis }\end{array}$ & 3 & 3 & 3 & 3.000 \\
\hline 2. & $\begin{array}{l}\text { Antusiasme } \\
\text { anak-anak dalam } \\
\text { mengikuti } \\
\text { kegiatan seni } \\
\text { sangat tinggi }\end{array}$ & 3 & 3 & 3 & 3.000 \\
\hline 3. & $\begin{array}{l}\text { Pelestarian nilai } \\
\text { Budaya } \\
\text { Tradisional } \\
\text { Melayu Jambi }\end{array}$ & 4 & 4 & 4 & 4.000 \\
\hline 4. & $\begin{array}{l}\text { Membuka } \\
\text { lapangan kerja } \\
\text { untuk para } \\
\text { seniman Jambi }\end{array}$ & 2 & 3 & 3 & 2.667 \\
\hline 5. & $\begin{array}{l}\text { Penyewaan } \\
\text { fasilitas yang } \\
\text { dimiliki sanggar } \\
\text { untuk } \\
\text { masyarakat } \\
\text { sekitar }\end{array}$ & 3 & 3 & 3 & 3.000 \\
\hline 6. & $\begin{array}{l}\text { Penyelenggaraan } \\
\text { kegiatan lomba } \\
\text { seni musik } \\
\text { Tradisional } \\
\text { Melayu Jambi } \\
\text { yang diikuti oleh } \\
\text { masyarakat } \\
\text { jambi }\end{array}$ & 3 & 4 & 4 & 3.667 \\
\hline
\end{tabular}

Gorga : Jurnal Seni Rupa

Volume 10 Nomor 02 Juli-Desember 2021 p-ISSN: 2301-5942 | e-ISSN: 2580-2380

Berdasarkan Tabel 10, peringkat terhadap peluang Sanggar Gong Sitimang yang terendah adalah "Membuka lapangan kerja untuk para seniman Jambi". Sedangkan peringkat yang tertinggi adalah "Pelestarian nilai Budaya Tradisional Melayu Jambi”.

\section{(d). Ancaman}

Tabel 11. Pemberian Peringkat Faktor Ancaman Sanggar Gong Sitimang

\begin{tabular}{|c|c|c|c|c|c|}
\hline No. & Ancaman & Zul & SW & Zami & $\begin{array}{l}\text { Rata- } \\
\text { Rata }\end{array}$ \\
\hline 1. & $\begin{array}{l}\text { Perubahan } \\
\text { sosial budaya, } \\
\text { lingkungan } \\
\text { demografi dan } \\
\text { ekonomi }\end{array}$ & 3 & 4 & 2 & 3.000 \\
\hline 2. & $\begin{array}{l}\text { Kemungkinan } \\
\text { besar akan } \\
\text { muncul pesaing } \\
\text { baru sanggar } \\
\text { seni musik } \\
\text { yang sejenis }\end{array}$ & 2 & 3 & 2 & 2.333 \\
\hline 3. & $\begin{array}{l}\text { Produk } \\
\text { pengganti } \\
\text { berupa hiburan } \\
\text { yang bukan } \\
\text { seni Tradisional }\end{array}$ & 3 & 4 & 1 & 2.667 \\
\hline 4. & $\begin{array}{l}\text { Penerus } \\
\text { generasi muda } \\
\text { semakin malu } \\
\text { untuk } \\
\text { berkesenian } \\
\end{array}$ & 3 & 3 & 1 & 2.333 \\
\hline 5. & $\begin{array}{l}\text { Sumber daya } \\
\text { yang mulai } \\
\text { berkurang }\end{array}$ & 2 & 3 & 1 & 2.000 \\
\hline
\end{tabular}

Berdasarkan Tabel 11, peringkat terhadap ancaman Sanggar Gong Sitimang yang terendah adalah "Sumber daya yang mulai berkurang". Sedangkan peringkat yang tertinggi adalah "Perubahan sosial budaya, lingkungan demografi dan ekonomi”.

\section{c. Hasil Matrik Internal Factor Evaluation (IFE)}

Tabel 12. Hasil Analisis Matrik IFE Sanggar Gong Sitimang

\begin{tabular}{|c|c|c|c|c|}
\hline No. & $\begin{array}{c}\text { Faktor } \\
\text { Internal }\end{array}$ & Bobot & $\begin{array}{l}\text { Peringk } \\
\text { at }\end{array}$ & Nilai \\
\hline \multicolumn{5}{|c|}{ Kekuatan } \\
\hline 1 & $\begin{array}{l}\text { Sudah berdiri sejak } \\
\text { tahun } 1990 \\
\text { (Berpengalaman) }\end{array}$ & 0.102 & 3.677 & 0.374 \\
\hline 2 & $\begin{array}{l}\text { Mempunyai Karakter } \\
\text { Tersendiri dalam } \\
\text { Karya musik } \\
\text { tradisional melayu } \\
\text { jambi yang mengikuti } \\
\text { perkembangan zaman }\end{array}$ & 0.087 & 4 & 0.348 \\
\hline 3 & $\begin{array}{l}\text { Seni yang } \\
\text { memprioritas generasi } \\
\text { muda }\end{array}$ & 0.088 & 4 & 0.352 \\
\hline 4 & $\begin{array}{l}\text { Memiliki tenaga } \\
\text { pengajar lulusan }\end{array}$ & 0.092 & 3.333 & 0.307 \\
\hline
\end{tabular}




\begin{tabular}{|c|c|c|c|c|}
\hline & $\begin{array}{l}\text { sekolah seni musik } \\
\text { dan sudah } \\
\text { berpengalaman } \\
\text { dibidangnya }\end{array}$ & & & \\
\hline 5 & $\begin{array}{l}\text { Pengemasan konsep } \\
\text { latihan yang menarik } \\
\text { dan kreatif }\end{array}$ & 0.082 & 3.667 & 0.301 \\
\hline 6 & $\begin{array}{l}\text { Memiliki hubungan } \\
\text { baik dengan para } \\
\text { konsumen }\end{array}$ & 0.085 & 3 & 0.225 \\
\hline 7 & $\begin{array}{l}\text { Dipercayai oleh } \\
\text { pemerintah, } \\
\text { Masyarakat dan } \\
\text { Media (televisi dan } \\
\text { radio) untuk mengisi } \\
\text { acara kesenian di } \\
\text { Jambi }\end{array}$ & 0.081 & 4 & 0.324 \\
\hline 8 & $\begin{array}{r}\text { Memiliki fasilitas } \\
\text { yang lengkap }\end{array}$ & 0.081 & 3.333 & 0.270 \\
\hline \multicolumn{4}{|c|}{ Total Nilai Kekuatan } & 2.260 \\
\hline \multicolumn{5}{|c|}{ Kelemahan } \\
\hline 9 & $\begin{array}{l}\text { Pengelolaan/manajemen } \\
\text { sanggar seni yang belum } \\
\text { maksimal }\end{array}$ & 0.070 & 2 & 0.140 \\
\hline 10 & $\begin{array}{l}\text { Belum mampu } \\
\text { melakukan pemetasan } \\
\text { sendiri untuk tingkat } \\
\text { nasional }\end{array}$ & 0.084 & 2.333 & 0.196 \\
\hline 11 & $\begin{array}{l}\text { Kurangnya Promosi di } \\
\text { Media Sosial }\end{array}$ & 0.070 & 2.333 & 0.163 \\
\hline 12 & $\begin{array}{l}\text { Belum jelasnya patokan } \\
\text { harga ketika di tawari } \\
\text { pentas }\end{array}$ & 0.076 & 2.667 & 0.203 \\
\hline \multicolumn{4}{|c|}{ Total Nilai Kelemahan } & 0.972 \\
\hline $\begin{array}{l}\text { Total } \\
\text { kelen }\end{array}$ & $\begin{array}{l}\text { kekuatan dan } \\
\text { ahan }\end{array}$ & 1,000 & - & 3.232 \\
\hline
\end{tabular}

Pada tabel 12, hasil analisis matrik IFE Sanggar Gong Sitimang yaitu nilai tertinggi adalah "Sudah berdiri sejak tahun 1990 (Berpengalaman)" yaitu sebesar 0,374, sedangkan yang terendah adalah "Pengelolaan/manajemen sanggar seni yang belum maksimal" sebesar 0,140 .

\section{d. Hasil Matrik External Factor Evaluation (EFE)}

Tabel 13. Hasil Analisis Matrik EFE Sanggar Gong Sitimang

\begin{tabular}{|c|l|c|c|c|}
\hline No & Faktor Eksternal & Bobot & $\begin{array}{c}\text { Peringka } \\
\mathbf{t}\end{array}$ & Nilai \\
\hline \multicolumn{1}{|l|}{ Peluang } \\
\hline 1. & $\begin{array}{l}\text { Belum banyak Sanggar } \\
\text { Seni yang sejenis }\end{array}$ & 0.107 & 3 & 0.321 \\
\hline
\end{tabular}

Gorga : Jurnal Seni Rupa

Volume 10 Nomor 02 Juli-Desember 2021 p-ISSN: 2301-5942 | e-ISSN: 2580-2380

\begin{tabular}{|c|c|c|c|c|}
\hline 2. & $\begin{array}{l}\text { Antusiasme anak-anak } \\
\text { dalam mengikuti } \\
\text { kegiatan seni sangat } \\
\text { tinggi }\end{array}$ & 0.077 & 3 & 0.231 \\
\hline 3. & $\begin{array}{l}\text { Pelestarian nilai Budaya } \\
\text { Tradisional Melayu } \\
\text { Jambi }\end{array}$ & 0.067 & 4 & 0.268 \\
\hline 4. & $\begin{array}{l}\text { Membuka lapangan } \\
\text { kerja untuk para } \\
\text { seniman Jambi }\end{array}$ & 0.084 & 2.667 & 0.224 \\
\hline 5. & $\begin{array}{l}\text { Penyewaan fasilitas } \\
\text { yang dimiliki sanggar } \\
\text { untuk masyarakat } \\
\text { sekitar }\end{array}$ & 0.117 & 3 & 0.351 \\
\hline 6. & \begin{tabular}{|l|} 
Penyelenggaraan \\
kegiatan lomba seni \\
musik Tradisional \\
Melayu Jambi yang \\
diikuti oleh masyarakat \\
jambi
\end{tabular} & 0.065 & 3.667 & 0.238 \\
\hline \multicolumn{4}{|c|}{ Total Nilai Peluang } & 1.633 \\
\hline \multicolumn{5}{|c|}{ Ancaman } \\
\hline 7. & $\begin{array}{l}\text { Perubahan sosial } \\
\text { budaya, lingkungan } \\
\text { demografi dan ekonomi }\end{array}$ & 0.092 & 3 & 0.276 \\
\hline 8. & $\begin{array}{l}\text { Kemungkinan besar } \\
\text { akan muncul pesaing } \\
\text { baru sanggar seni musik } \\
\text { yang sejenis }\end{array}$ & 0.089 & 2.333 & 0.208 \\
\hline 9. & $\begin{array}{l}\text { Produk pengganti } \\
\text { berupa hiburan yang } \\
\text { bukan seni Tradisional }\end{array}$ & 0.100 & 2.667 & 0.267 \\
\hline 10. & $\begin{array}{l}\text { Penerus generasi muda } \\
\text { semakin malu untuk } \\
\text { berkesenian }\end{array}$ & 0.100 & 2.333 & 0.233 \\
\hline 11. & $\begin{array}{l}\text { Sumber daya yang } \\
\text { mulai berkurang }\end{array}$ & 0.100 & 2 & 0.200 \\
\hline \multicolumn{4}{|c|}{ Total Nilai Ancaman } & 1.184 \\
\hline Total & geluang dan ancaman & 1,000 & - & 2.817 \\
\hline
\end{tabular}

Pada Tabel 13, hasil analisis matrik EFE Sanggar Gong Sitimang yaitu nilai tertinggi adalah "Penyewaan fasilitas yang dimiliki sanggar untuk masyarakat sekitar" sebesar 0,351, sedangkan yang terendah adalah "Sumber daya yang mulai berkurang" sebesar 0,200.

\section{(2). Tahap Pencocokan}

Hasil perhitungan yang sudah dibahas sebelumnya, hasil IFE yang diperoleh sebesar 3.232 dan EFE sebesar 2.817. Dari angka tersebut dapat menggambarkan posisi keberapa Sanggar Gong Sitimang 
Tabel 14. Matrik $I E$ Sanggar Gong Sitimang

\begin{tabular}{|c|c|c|c|c|}
\hline \multirow{5}{*}{ 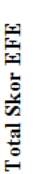 } & \multicolumn{4}{|c|}{ Total Skor IFE } \\
\hline & 4.00 & $3.0 \mathrm{c}$ & 2.00 & 1.00 \\
\hline & 3.00 & I & II & III \\
\hline & 2.00 & 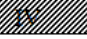 & $\mathrm{V}$ & VI \\
\hline & 1.00 & VII & VIII & IX \\
\hline
\end{tabular}

Posisi usaha pada Sanggar Gong Sitimang melalui Matriks IE menunjukkan Growth and Build (tumbuh dan bina) karena berada pada posisi IV. Strategi yang cocok adalah intensif (penetrasi pasar, pengembangan pasar, danpengembangan produk) atau integrasi (integrasi ke belakang, integrasi ke depan dan integrasi horizontal).

Dengan strategi penetrasi pasar, pengembangan pasar dan pengembangan produk, maka dengan ini disarankan Sanggar Gong Sitimang melakukan inovasi inovasi dalam permainan alat musik dan aransemen musik tradisional Jambi sehingga sesuai dengan perkembangan zaman. Menjalin kerjasama dengan pemerintah daerah dan sarana informasi berupa surat kabar, TV dan radio lokal yang ada di Jambi sebagai sarana pemasaran. Melakukan analisis dan evaluasi secara terus menerus terhadap lingkungan eksternal dan internal untuk menunjang semangat dan produktifitas anggota Sanggar Gong Sitimang dalam berkarya. Perlunya membuat pengelompokan tarif untuk pementasan dan peminjaman alat dan lain lain. Perlu dibuatnya managemen informasi dan komunikasi yang update dan selalu siap melayani permintaan pelanggan. Dan dibuatnya managemen yang mengelola keuangan sendiri di luar Sanggar Gong Sitimang.

\section{a. Kuadran Analisis SWOT}

Untuk kuadran analisis SWOT Sanggar Gong Sitimang dihitung berdasarkan berikut:

$$
\begin{gathered}
\text { Nilai Faktor Internal } \\
=\text { Kekuatan }- \text { Kelemahan } \\
=\mathbf{2 . 2 6 0}-\mathbf{0 . 9 7 2} \\
=\mathbf{1 . 2 8 8} \\
\text { Nilai Faktor Eksternal } \\
=\text { Peluang }- \text { Ancaman } \\
=\mathbf{1 . 6 3 3}-\mathbf{1 . 1 8 4} \\
=\mathbf{0 . 4 4 9}
\end{gathered}
$$

Gorga : Jurnal Seni Rupa

Volume 10 Nomor 02 Juli-Desember 2021 p-ISSN: 2301-5942 | e-ISSN: 2580-2380

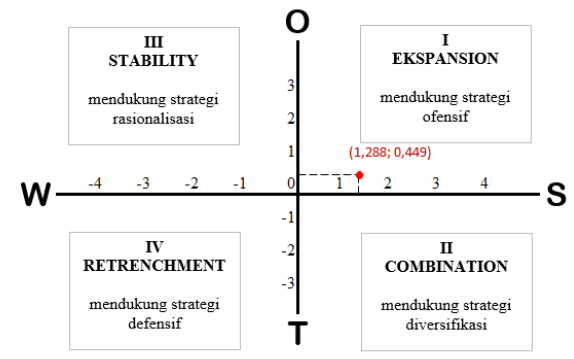

Gambar 1. Kuadran Analisis SWOT Sanggar Gong Sitimang

Kuadran Analisis SWOT Sanggar Gong Sitimang menunjukkan posisinya berada pada kuadran I yang dimana pada kuadran satu ini dikatakan dalam posisi yang bagus sehingga Sanggar Gong Sitimang untuk terus menjalankan strateginya dengan baik, dimana sanggar ini harus terus ekspansi, memperbesar pertumbuhan dan bisa meraih kemajuan secara maksimal. Dengan mengikuti trend yang lagi trending topik di daerah Jambi dapat memberikan variasi hasil aransemen musik tradisional Jambi. Selau update untuk memberikan iklan di media komunikasi yang mendukung seperti radio tv dan media social lainnya. Dan menetapkan harga sewa dan pementasan yang terjangkau oleh masyarakat.

Selanjutnya adalah perumusan strategi-strategi melalui matriks SWOT yang diperoleh dengan memasangkan faktor-faktor eksternal dengan faktor-faktor internal. Dalam matriks SWOT diperlihatkan kesesuaian antara kekuatan, kelemahan, peluang dan ancaman.

\begin{tabular}{|c|c|c|}
\hline Internal & Kekuatan (S) & Kelemahan (W) \\
\hline Peluang (O) & $\begin{array}{l}\text { Strategi SO } \\
\text { Ciptakan strategi yang } \\
\text { menggunakan kekuatan } \\
\text { untuk memanfaatkan } \\
\text { peluang }\end{array}$ & $\begin{array}{l}\text { Strategi WO } \\
\text { Ciptakan strategi } \\
\text { yang } \\
\text { meminimalkan } \\
\text { kelemahan untuk } \\
\text { memanfaatkan } \\
\text { peluang }\end{array}$ \\
\hline Ancaman (T) & $\begin{array}{l}\text { Strategi ST } \\
\text { Ciptakan strategi yang } \\
\text { menggunakan kekuatan }\end{array}$ & $\begin{array}{l}\text { Strategi TW } \\
\text { Ciptakan strategi } \\
\text { yang }\end{array}$ \\
\hline
\end{tabular}

\section{b. Matrik SWOT}

Matriks SWOT diperoleh dengan memasangkan faktorfaktor eksternal dengan faktor-faktor internal (Natonis, 2016). Dalam matriks SWOT diperlihatkan kesesuaian antara kekuatan, kelemahan, peluang dan ancaman seperti terlihat pada tabel berikut.

Tabel 15. Alternatif Strategi dalam Matriks SWOT 


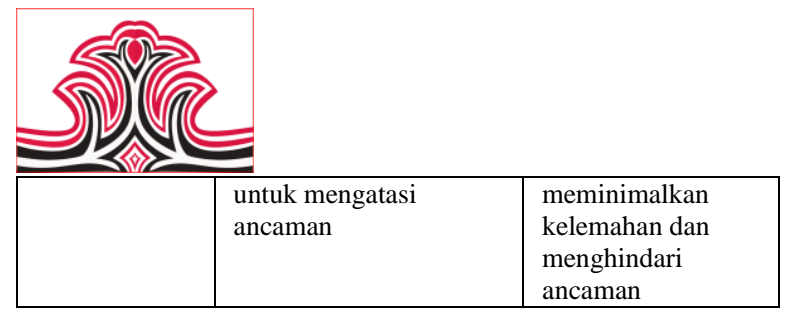

Berdasarkan hasil Kuadran Analisis SWOT Sanggar Gong Sitimang menunjukan posisinya berada pada kuadran I yaitu Ekspansions yang dimana strategi ini mendukung strategi ofensif. Selanjutnya akan dibuat tabel matriks SWOT adalah sebagai berikut:

Tabel 16. Alternatif Strategi Sanggar Gong Sitimang dalam Matriks

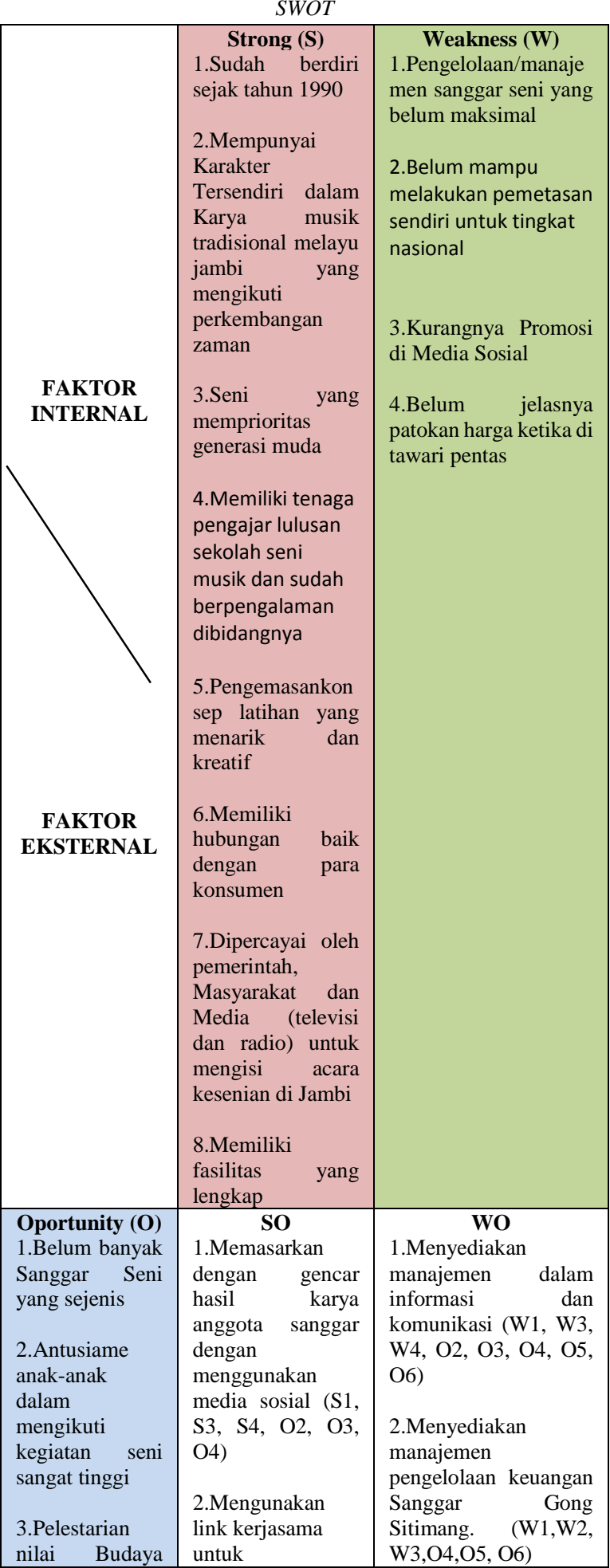

Gorga : Jurnal Seni Rupa

Volume 10 Nomor 02 Juli-Desember 2021 p-ISSN: 2301-5942 | e-ISSN: 2580-2380

\begin{tabular}{|c|c|c|}
\hline $\begin{array}{l}\text { Tradisional } \\
\text { Melayu Jambi } \\
\text { 4.Membuka } \\
\text { lapangan kerja } \\
\text { untuk para } \\
\text { seniman Jambi } \\
\text { 5.Penyewaan } \\
\text { fasilitas yang } \\
\text { dimiliki sanggar } \\
\text { untuk } \\
\text { masyarakat } \\
\text { sekitar } \\
\text { 6.Penyelenggar } \\
\text { aan kegiatan } \\
\text { lomba seni } \\
\text { musik } \\
\text { Tradisional } \\
\text { Melayu Jambi } \\
\text { yang diikuti } \\
\text { oleh masyarakat } \\
\text { jambi }\end{array}$ & $\begin{array}{l}\text { mendapatkan } \\
\text { perhatian } \\
\text { masyarakat (S3, } \\
\text { S7, O1, O2, O6) } \\
\text { 3.Mengelompokk } \\
\text { an tariff yang } \\
\text { terjangkau bagi } \\
\text { masyarakat dalam } \\
\text { penyewaan dan } \\
\text { pementasan seni } \\
\text { (S6,S7,S8,O4,O5) } \\
\text { 3.Melakukan } \\
\text { pementasan dan } \\
\text { perlombaan yang } \\
\text { diadakan secara } \\
\text { periodic tiap tahun } \\
\text { dengan } \\
\text { mengundang } \\
\text { seluruh civitas } \\
\text { yang ada di Jambi. } \\
\text { (S5,S6,S7, O2, } \\
\text { O3, O6) }\end{array}$ & \\
\hline $\begin{array}{l}\text { Threat (T) } \\
\text { 1.Perubahan } \\
\text { sosial budaya, } \\
\text { lingkungan } \\
\text { demografi dan } \\
\text { ekonomi } \\
\text { 2.Kemungkinan } \\
\text { besar akan } \\
\text { muncul pesaing } \\
\text { baru sanggar } \\
\text { seni musik yang } \\
\text { sejenis } \\
\text { 3.Produk } \\
\text { pengganti } \\
\text { berupa hiburan } \\
\text { yang bukan seni } \\
\text { Tradisional } \\
\text { 4.Penerus } \\
\text { generasi muda } \\
\text { semakin malu } \\
\text { untuk } \\
\text { berkesenian } \\
\text { 5.Sumber daya } \\
\text { yang mulai } \\
\text { berkurang }\end{array}$ & $\begin{array}{l}\text { ST } \\
\text { 1.Menawarkan } \\
\text { pelatihan yang } \\
\text { nyaman dan } \\
\text { menyenangkan } \\
(\mathrm{S} 1, \mathrm{~S} 2, \mathrm{~S} 3, \mathrm{~T} 1) \\
\text { 2.Menjalin } \\
\text { kerjasama yang } \\
\text { baik dengan } \\
\text { konsumen (S4, S6, } \\
\text { S7, O1, O4, O5) } \\
\text { 3.Menawarkan } \\
\text { inovasi inovasi } \\
\text { baru dalam } \\
\text { berkesenian baik } \\
\text { dalam aransemen } \\
\text { music tradisional } \\
\text { dan mengikutsertakan } \\
\text { mentar } \\
\text { alat music } \\
\text { tradisonal ke } \\
\text { dalam instrument } \\
\text { music modern (S2, } \\
\text { S5, O1, O2, O3) }\end{array}$ & \begin{tabular}{lr}
\multicolumn{2}{c}{ WT } \\
1.Perlu & perubahan \\
tatanan & sistem \\
organisasi & dalam \\
pelatihan, & periklanan \\
dan & manajemen \\
keuangan (W1, W2, & W3, W4,T1)
\end{tabular} \\
\hline
\end{tabular}

\section{(3). Tahap Keputusan}

Hasil Matriks SWOT memberikan beberapa alternatif strategi, yaitu:

SO 1. Memasarkan dengan gencar hasil karya anggota sanggar dengan menggunakan media sosial (S1, S3, S4, O2, O3, O4)

2. Mengunakan link kerjasama untuk mendapatkan perhatian masyarakat (S3, S7, $\mathrm{O} 1, \mathrm{O} 2, \mathrm{O} 6)$

3. Mengelompokkan tariff yang terjangkau bagi masyarakat dalam penyewaan dan pementasan seni (S6,S7,S8,O4,O5)

4. Melakukan pementasan dan perlombaan yang diadakan secara periodic tiap tahun dengan mengundang seluruh civitas yang ada di Jambi. (S5,S6,S7, O2, O3, O6)

WO 1. Menyediakan manajemen dalam informasi dan komunikasi (W1, W3, W4, O2, O3, O4, O5, O6) 


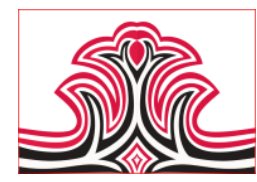

2. Menyediakan manajemen pengelolaan keuangan Sanggar Gong Sitimang. (W1,W2, W3, O4,O5, O6)

ST 1. Menawarkan pelatihan yang nyaman dan menyenangkan $(\mathrm{S} 1, \mathrm{~S} 2, \mathrm{~S} 3, \mathrm{~T} 1)$

2. Menjalin kerjasama yang baik dengan konsumen (S4, S6, S7, O1, O4, O5)

3. Menawarkan inovasi inovasi baru dalam berkesenian baik dalam aransemen music tradisional dan mengikutsertakan alat music tradisonal ke dalam instrument music modern (S2, S5, O1, O2, O3)

WT 1) Perlu perubahan tatanan sistem organisasi dalam pelatihan, periklanan dan manajemen keuangan (W1, W2, W3, W4,T1)

\section{Pembahasan}

Pada tahap keputusan berdasarkan Matriks IE posisi Sanggar Gong Sitimang ini menunjukkan Growth and Build (tumbuh dan bina) karena berada pada posisi IV. Maka dari itu strategi yang cocok adalah intensif (penetrasi pasar, pengembangan pasar, dan pengembangan produk) atau integrasi (integrasi ke belakang, integrasi ke depan dan integrasi horizontal).

\section{1). Intensif}

Penetrasi Pasar: Memasarkan dengan gencar kegiatan sanggar dan karya karya anggota sanggar dengan menggunakan media komunikasi dan media sosial. Pengembangan Pasar: Menambah dan memperluas jaringan kerjasama dengan pemerintah daerah, sekolahsekolah, dan lainnya. Pengembangan Produk: Mendokumentasikan setiap kegiatan berupa aransemen musik tradsional, lomba-lomba dan lainnya.

\section{2). Integrasi}

Integrasi strategi yang digunakan adalah Integrasi ke Belakang yaitu, mampu melakukan evaluasi dari setiap kegiatan yang telah dilakukan untuk menjadi pembelajaran selanjutnya. Dari alternatif strategi matrik SWOT memang strategi ini tidak dihasilkan, tetapi untuk saat sekarang inilah strategi yang diterapkan oleh Sanggar Gong Sitimang. Sedangkan tahap keputusan berdasarkan kuandran analisis SWOT posisi Sanggar Gong Sitimang menunjukkan pada kuadran I Ekspansion sehingga diperlukan pemilihan strategi yang berupa penggunaan setiap kekuatan untuk menghadapi setiap ancaman dengan menggunakan strategi ofensif. Posisi tersebut mengarah pada strategi ST yaitu : 1). Menjaring anggota dan memperluas cakupan dengan menghasilkan karya-karya yang inovatif untuk menarik minat masyarakat untuk ikut terlibat. 2). Mempertahankan eksistensi dengan memperbanyak melakukan pementasan agar lebih dikenal oleh masyarakat luas.
Gorga : Jurnal Seni Rupa

Volume 10 Nomor 02 Juli-Desember 2021

p-ISSN: 2301-5942 | e-ISSN: 2580-2380

\section{KESIMPULAN DAN SARAN}

\section{Kesimpulan}

Berdasarkan penjabaran yang sudah dipaparkan sebelumnya, maka dapat disimpulkan sebagai berikut, Strategi pengelolaan Sanggar Gong Sitimang dilihat dari hasil analisa matrik IE posisi Sanggar Gong Sitimang ini beerada di posisi IV, dimana sanggar gong sitimang menunjukkan Growth and Build yang artinya tumbuh dan bina. untuk variasi strategi yang cocok pada sanggar gong sitimang ini adalah Intensif atau Integrasi. Sedangkan menurut hasil kuadran SWOT posisi sanggar gong sitimang berada pada kuadran I yaitu Strategi generik Ekspansion. Jadi variasi strategi yang digunakan adalah ofensif (variasi strategi kuadran SWOT), Intensif \& Integrasi (variasi strategi dari matrik IE). Maka dari itu berdasarkan analisa Matrik IE (Internal-Eksternal) dan Kuadran SWOT dapat disimpulkan strategi usaha Gong Sitimang sebagai berikut:

Tabel 17. Strategi Genetik

\begin{tabular}{|c|c|c|}
\hline $\begin{array}{l}\text { Strategi } \\
\text { Genetik }\end{array}$ & & Ekspansion \\
\hline $\begin{array}{l}\text { Variasi } \\
\text { Strategi }\end{array}$ & 3) & $\begin{array}{l}\text { Penetrasi Pasar: Memasarkan } \\
\text { dengan gencar kegiatan sanggar } \\
\text { dan karya karya anggota sanggar } \\
\text { dengan menggunakan media } \\
\text { komunikasi dan media sosial. } \\
\text { Pengembangan Pasar: } \\
\text { Menambah dan memperluas } \\
\text { jaringan kerjasama dengan } \\
\text { pemerintah daerah, sekolah- } \\
\text { sekolah, dan lainnya. } \\
\text { Pengembangan Produk: } \\
\text { Mendokumentasikan setiap } \\
\text { kegiatan berupa aransemen } \\
\text { music tradisional, lomba-lomba } \\
\text { dan lainnya. } \\
\text { Integrasi ke Belakang yaitu } \\
\text { mampu melakuakan evaluasi } \\
\text { dari setiap kegiatan yang } \\
\text { dilakukan untuk diambil } \\
\text { pelajarannya untuk kemajuan } \\
\text { Sanggar Gong Sitimang. }\end{array}$ \\
\hline
\end{tabular}

\section{Saran}

Berdasarkan dari analisis SWOT dalam strategi pengelolaan Sanggar Gong Sitimang, sanggar perlu melakukan kegiatan pemasaran melalui media sosial secara terus-menerus supaya kegiatan dan karya seni musik sanggar lebih dikenal oleh masyarakat luas. Selanjutnya pengelola sanggar perlu menambah jaringan kerja sama dengan stakeholder eksternal yaitu pemerintah, sekolah-sekolah, dan media, kerja sama ini dilakukan supaya keberlangsungan hidup sebuah sanggar seni selalu terjaga dan dipercayai masyarakat. Seandainya ada peneliti lain yang ingin melanjutkan penelitian Strategi Pengelolaan Sanggar Gong Sitimang ini, apabila ada kekurangan dari teori, saya berharap peneliti harus ada pembaruan dalam strategi 
pengelolaan dengan teori strategi yang lebih tepat. Selain itu Penelitian ini hanya menggunakan metode kualitatif, sedangkan untuk mendapatkan data penelitian yang valid seharusnya peneliti juga menggunakan metode kuantitatif dalam menganalisisi analisis SWOT pada strategi pengelolaan Sanggar Gong Sitimang.

\section{DAFTAR RUJUKAN}

Albertus, P. S. (2020). Analisis SWOT dalam

Penentuan Strategi Pemasaran untuk

Peningkatan Penjualan Mesin Diesel.

https://resposity

.usd.ac.id/38258/2/152214193_full.pdf

(diakses 18 Maret 2021).

David, F. R. (2016). Manajemen Strategi, Edisi 15.

Jakarta: Salemba Wmpat.

Erwin, S. (2014). Analisis SWOT Dalam

Bisnis. Bandung. Kata Pena.

Kartika, R. Y. (2017). Strategi Pengelolaan Sanggar Seni Sidoum di Kota Langsa, Aceh. Jurnal Tata Kelola Seni, 3(2), 54-68.

Natonis, R. J. I. (2016). Strategi Pengelolaan Pusat Musik Liturgi Yogyakarta. Jurnal Tata Kelola Seni, 2(2), 66-80.

Rangkuti, F. (2016). Teknik Membedakan Kasus Bisnis Analisis SWOT. Jakarta: PT Gramedia.

Sondang, P. S. (2000). Manajemen Strategi. Jakarta: PT Bumi Aksara.

Sugiyono. (2011). Metode Penelitian Kuantitatif Kualitatif dan $R \& D$. Bandung: Alfabeta. 